\title{
Clinicopathological analysis of ovarian tumors: a two year retrospective study
}

\author{
Kanika Chandra, Neetu Arora* \\ Department of Obstetrics and Gynecology, Shri Guru Ram Rai Institute of Medical and Health Sciences, Dehradun, \\ Uttarakhand, India
}

Received: 16 May 2019

Revised: 04 July 2019

Accepted: 08 July 2019

\section{*Correspondence:}

Dr. Neetu Arora,

E-mail: rometraneetu@gmail.com

Copyright: ( ) the author(s), publisher and licensee Medip Academy. This is an open-access article distributed under the terms of the Creative Commons Attribution Non-Commercial License, which permits unrestricted non-commercial use, distribution, and reproduction in any medium, provided the original work is properly cited.

\section{ABSTRACT}

Background: Ovarian tumours are a heterogeneous neoplasm with a varied clinical, morphological and histological feature. Increasing mortality rate due to ovarian cancers has been reported in recent years. Ovarian tumours in postmenopausal females have high risk of malignancy and it has a very poor outcome. The aim and objective of this study was to determine clinical and histopathological spectrum and the frequency and age distribution of various ovarian tumors.

Methods: It is a retrospective observational study of patients with ovarian tumors in the department of obstetrics and gynecology, SGRRI of Medical Health \& Sciences and Hospital from January 2016 to December 2017 in a total number of 86 patients. All specimens were sent to pathology department and categorised according to WHO hispathological classification.

Results: Out of 86 cases examined, 64 cases were benign (74.4\%), 3 cases were borderline (3.4\%) and 19 cases were malignant $(22.2 \%)$. Majority of the ovarian tumors (73.4\%) were seen in the age group of 20 to 50 years. Most commonly encountered benign ovarian tumour was serous cystadenoma (58.1\%). Surface epithelial tumors were the commonest tumors $(64 \%)$ followed by germ cell tumors (29\%).

Conclusions: A variety of benign and malignant tumours of ovary were reported in this study. Early diagnosis and appropriate treatment of ovarian neoplasms favour the good prognosis. Most common benign tumour encountered in this study was serous cystadenoma.

Keywords: Benign, Borderline, Epithelial tumours, Germ cell tumours, Histopathology, Malignant, Mature cystic teratoma, Ovarian tumours, Serous, Sex cord stromal tumours

\section{INTRODUCTION}

Ovarian tumour, a common neoplasm in women, can present as either benign or malignant tumor. Ovarian tumours are complex neoplasms involving variety of histological tissues such as epithelial tissues, hormone secreting cells, connective tissues to germinal and embryonal cells. Ovarian tumours are encountered in about $5 \%$ of gynaecological admissions. Ovarian cysts of benign nature may occur at any point in the life, but they are most common during childbearing age and constitute about $90 \%$ of ovarian tumors. ${ }^{1}$ It occurs mainly in postmenopausal and reproductive women, uncommon in children. Ovarian tumours in post-menopausal women has high risk of malignancy and very poor outcome. ${ }^{1}$

About $80 \%$ of ovarian neoplasms are benign and these occur mostly in young women between the ages of 20 
and 45 years. $^{2}$ The malignant tumours are more common in older women between the ages of 40 and 65 years. ${ }^{2}$ Tumors of the ovary are a common neoplasm in women. ${ }^{3}$ The most common lesions encountered in the ovary are functional or benign cysts and tumors. ${ }^{4}$ Ovarian cancer is the sixth most common female cancer and is seen predominantly after the third decade of life. ${ }^{5}$ Ovarian neoplasms are usually detected at a late stage and are large in size, because of their presentation with mild symptoms. ${ }^{6}$ There is no reliable means for early detection except for accurate histopathological diagnosis that facilitates the effective treatment of ovarian tumours. ${ }^{7}$

Japan and Asian countries have rates of 2-6.5 new cases per 100,000 women per year. ${ }^{8}$ Most ovarian cancers have spread beyond the ovary by the time of diagnosis, they account for a disproportionate number of deaths from cancer of the female genital tract. ${ }^{9}$

The most common symptoms are due to abdominal pain and distension or tumor compression on urinary and gastrointestinal tract. Other symptoms are bleeding per vaginum and invasion of neighbouring structures. ${ }^{10}$ The cause of ovarian neoplasms have been based on hypothesis proposed by Fathalla. ${ }^{11}$ Determination of various histological patterns of primary ovarian tumour is very important in diagnosis, treatment as well as prognostication. ${ }^{6}$ Prognosis of the tumours can also be predicted from the degree of differentiation of the tumours. ${ }^{6}$ The stage and laterality of the tumour also indicates their nature; for example, tumours in the sex cord stromal category are almost always confined to a single ovary. ${ }^{6}$

\section{METHODS}

It was a retrospective observational study of patients with ovarian tumors in the department of obstetrics and gynecology, SGRRI of Medical and health Sciences and Hospital from January 2016 to December 2017. Total number of patients studied were 86 in number.

After detailed history, examination and investigation, probable diagnosis was made, and they were operated upon. All specimens were sent to pathology department and categorized according to WHO histopathological classification.
The data were collected on a proforma, which consists of the relevant information about parity, age, size of tumor, bilaterality, family history of cancer, personal history of previous malignancies, symptoms and the duration of symptoms. Leading symptoms such as abdominal mass, abdominal swelling/ discomfort, abdominal pain, gastrointestinal symptoms, urinary symptoms, generalized malaise and fatigue were scrutinized.

\section{Inclusion criteria}

All histologically proven both primary and secondary ovarian tumours.

\section{Exclusion criteria}

Non- neoplastic or tumour like lesions of ovary were excluded.

All patients underwent routine physical examination. Particular attention was paid to breast examination, lymphadenopathy, abdominal examination and pelvic examination. Preoperative evaluation included routine investigations, estimation of serum CA 125, assessment of cardiovascular system, imaging studies and radiography of chest. After Laparotomy all specimens were sent to pathology department and categorised according to WHO hispathological classification.The statistical analysis was done on the basis of percentage distribution of the total number of patients.

\section{RESULTS}

Out of 86 cases examined in this study, 64 cases were benign (74.4\%), 3 cases were borderline (3.4\%) and 19 cases were malignant $(22.2 \%)$. Majority of the ovarian tumors $(73.4 \%)$ were seen in the age group of 20 to 50 years. The youngest patients presented in this study were 4 in between 15-18 years. Histopathological diagnosis was serous cyst adenoma in two patient and mature teratoma in other (Table 1).The oldest patient in this study was a 75 year-old, who had come to the Gynaecology OPD with history of foul-smelling white discharge per vaginum and occasional spotting. This was a case of endometrioid carcinoma of ovary.

Table 1: On the basis of age distribution (n-number of cases).

\begin{tabular}{|llll|}
\hline Age in years & Benign $(\mathbf{n})$ & Borderline $(\mathbf{n})$ & Malignant $(\mathbf{n})$ \\
\hline$<20$ & 4 & 0 & 1 \\
\hline $21-30$ & 14 & 0 & 5 \\
\hline $31-40$ & 21 & 0 & 2 \\
\hline $41-50$ & 12 & 2 & 6 \\
\hline $51-60$ & 10 & 0 & 1 \\
\hline $61-70$ & 5 & 1 & 3 \\
\hline$>70$ & 2 & 0 & 1 \\
\hline Total $n$ (no. of cases) & 4 & 3 & 19 \\
\hline
\end{tabular}


Table 2: Clinical presentation in ovarian tumours.

\begin{tabular}{|lcc|}
\hline Common Symptoms & No. of cases (n) & Percentage \% \\
\hline Abdominal discomfort & 79 & 92.5 \\
\hline Abdominal distension & 76 & 89.2 \\
\hline Menstrual irregularities & 46 & 54.2 \\
\hline Pelvic pain & 22 & 26.5 \\
\hline Constipation & 8 & 9.4 \\
\hline Intermittent intestinal obstruction & 2 & 2.3 \\
\hline Mass per abdomen+ menstrual irregularity+ ascites (triad) & 2 & 2.3 \\
\hline Positive family history & 10 & 8.6 \\
\hline
\end{tabular}

Table 3: Frequency of histological types of ovarian tumours based on cell of origin.

\begin{tabular}{|lll|}
\hline Histology Types & Number & Percentage \\
\hline Surface epithelial tumour & 55 & $64 \%$ \\
\hline Sex cord tumour & 1 & $1.16 \%$ \\
\hline Germ cell tumour & 25 & $29 \%$ \\
\hline Metastatic tumour & 4 & $4.16 \%$ \\
\hline
\end{tabular}

Table 4: Laterality of ovarian tumours in the present study.

\begin{tabular}{|lll|}
\hline Histological types & Unilateral & Bilateral \\
\hline Surface epithelial tumour & & \\
\hline Benign & & \\
\hline Serous cystadenoma & 27 & 4 \\
\hline Mucinouus cystadenoma & 7 & 2 \\
\hline Endometrioid & 0 & 0 \\
\hline Borderline & & \\
\hline Serous cystadenoma & 2 & 0 \\
\hline Mucinous cystadenoma & 1 & 0 \\
\hline Endometrioid & 0 & 0 \\
\hline Malignant & & \\
\hline Serous cystadenoma & 3 & 1 \\
\hline Mucinous cystadenoma & 6 & 1 \\
\hline Endometrioid & 0 & 1 \\
\hline Germ cell tumour & & \\
\hline Dermoid cyst & 20 & 3 \\
\hline Endoderma sinus tumour & 1 & 0 \\
\hline Embryonal carcinoma & 1 & 0 \\
\hline Sex cord tumour & & \\
\hline Granulosa cell tumour & 1 & 0 \\
\hline Metastatic tumour & 0 & 4 \\
\hline Epidermoid cyst & 1 & 16 \\
\hline Total number & 70 & $18.6 \%$ \\
\hline Percentage & $81.39 \%$ \\
\hline
\end{tabular}

In the present study, the most common symptom with which patient presented was Abdominal discomfort in 79 cases $(92.5 \%)$, followed by Abdominal distension in 76 cases $(89.2 \%)$ and then Menstrual irregularities in 46 cases $(54.2 \%)$, Pelvic pain was seen in 22 cases $(26.4 \%)$,
Constipation in 8 cases (9.4\%), Intermittent intestinal obstruction in 2 cases $(2.3 \%)$ and $2(2.3 \%)$ patients had presented with the triad of symptoms of mass per abdomen, menstrual symptoms and ascites. The most common symptom for both benign and malignant tumours is Abdominal discomfort, Acute pain in benign tumour was mostly associated with torsion, and chronic pain was associated with large tumours with increased chance of malignancy. Positive family history was seen in 10 cases $(8.6 \%)$ (Table 2).

In the present study, maximum frequency of cases on the basis of histology was seen in Surface Epithelial Tumour which was $64 \%$ followed by Germ Cell tumour which was 29\%, then Metastatic Tumour 4.16\% and least was seen in sex cord stromal tumours i.e. $1.16 \%$ (Table 3). In the present study, out of 86 maximum number of cases i.e. 70 were found to have unilateral involvement $81.39 \%$ of which 32 were Serous cystadenoma, 14 were Mucinous cystadenoma, 20 Dermoid cyst as compared to Bilateral involvement which was seen in 16 cases i.e $18.6 \%$ of which 5 were Serous cystadenoma, 3 Mucinous cystadenoma, 3 Dermoid cyst and 4 Metastatic tumour (Table 4).

Table 5: Stage wise distribution of malignant ovarian tumour.

\begin{tabular}{|lc|}
\hline Stage & Frequency \\
\hline I & 2 \\
\hline II & 5 \\
\hline III & 8 \\
\hline IV & 4 \\
\hline Total & 19 \\
\hline
\end{tabular}

Table 5 shows that in the present study out of 19 , maximum number of cases were 8 which were seen in Stage III of Malignancy, it was followed by Stage II in which the frequency was 5 in number, then comes the Stage IV in which it was only 4 cases and lastly the Stage I which had only 2 cases.

\section{DISCUSSION}

Ovarian tumours are one of the major health problems and their diagnosis can be difficult due to variety of pathologic 
conditions affecting the ovaries. Thus, knowledge of morphology and age-specific characteristics can help refine the diagnosis. Typically, ovarian masses consist of functional and pathological lesions. ${ }^{12}$ Given the location of these paired organs and the mildness of symptoms associated with lesions arising in them, these lesions usually attain a fairly large size before they are detected and removed. ${ }^{13,14}$ Diagnosis of ovarian tumors is challenged by diverse pathologic conditions that can affect the ovaries and present with similar clinical and radiologic manifestations. The diagnosis can be refined by the knowledge of morphology and age-specific characteristics. ${ }^{15}$ From Table 1 , it is evident that benign tumours constitute more than $60 \%$ of all ovarian tumours and occurs more commonly in the 20 50 years age group. Surface epithelial tumours of ovary are most common of ovarian tumours in our study $(64 \%)$ which correlates with studies by Gupta et al, (54.7\%), Badge et al, and Francisco et al, (70.2\%). ${ }^{16-18}$ Among benign surface epithelial tumours, serous cystadenomas were most common, which was different from study by Mankar et al, But studies by other authors like Shah et al, and Thanikachalam et al, show that Serous Cystadenomas were the most common benign ovarian tumours. ${ }^{19}$ The highest number of malignant tumours were diagnosed in the 41-60 years age group in the Mankar et al, study. ${ }^{19}$ In this study the lowest age group for malignancy was 26 years pointing out to an increasing incidence of malignancy in the age group less than 40 years.

Table 6: Laterality of ovarian neoplastic lesions in various studies in comparison with present study.

\begin{tabular}{|lll|}
\hline Authors & Unilateral & Bilateral \\
\hline Prabhakar et al, $(1989)^{20}$ & $90.9 \%$ & $9.1 \%$ \\
\hline Misra et al, $(1990)^{21}$ & $95.5 \%$ & $4.5 \%$ \\
\hline Couto F et al, $(1993)^{22}$ & $91.2 \%$ & $8.7 \%$ \\
\hline Kar et al, $(2005)^{23}$ & $73.13 \%$ & $26.8 \%$ \\
\hline Present Study & $81.39 \%$ & $18.6 \%$ \\
\hline
\end{tabular}

Laterality of ovarian neoplastic lesions in various studies in comparison with present study is illustrated in Table 6 . This study revealed that majority of the tumours were Unilateral i.e. 70 out of 86 ovarian specimens were unilateral $(81.39 \%)$ and only $16(18.6 \%)$ were bilateral. This finding is in concordance with other studies Kar et al, 73.13\% Unilateral and 18.6\% Bilateral and Prabhakar et al, 1989 with $90.9 \%$ Unilateral and $9.1 \%$ Bilateral. $^{23}$ Misra et al, 1990 study showed that $95.5 \%$ of cases were unilateral and $4.5 \%$ of cases were bilateral. ${ }^{20,21}$

Table 7: Comparative analysis of frequency of ovarian neoplasms based on cell of origin.

\begin{tabular}{|lllll|}
\hline Study & $\begin{array}{l}\text { Epithelial } \\
\text { tumours (ET) \% }\end{array}$ & $\begin{array}{l}\text { Germ cell tumour } \\
(\text { GCT) \% }\end{array}$ & $\begin{array}{l}\text { Sex cord stromal } \\
\text { tumours (SST) \% }\end{array}$ & $\begin{array}{l}\text { Metastatic } \\
\text { tumours \% }\end{array}$ \\
\hline Jha R and Karki S ${ }^{24}$ & 52.2 & 42.2 & 3.1 & 2.4 \\
\hline Couta F et al, ${ }^{22}$ & 68.81 & 20.39 & 8.3 & 1.46 \\
\hline Badge S et al, ${ }^{17}$ & 77 & 16 & 6 & 1 \\
\hline Swati et al, ${ }^{26}$ & 69.17 & 25.83 & 4.17 & 0.83 \\
\hline Present study & 64 & 29 & 1.16 & 4.65 \\
\hline
\end{tabular}

Table 8: Comparative analysis of cases based on nature of tumours.

\begin{tabular}{|llll|}
\hline Study & Benign $(\%)$ & Borderline $(\%)$ & Malignant (\%) \\
\hline Couto F et al, & 80.76 & 2.33 & 16.91 \\
\hline Gupta et al, ${ }^{16}$ & 59.4 & 0.6 & 40.0 \\
\hline Kuladeepa AVK et al, $^{26}$ & 82.35 & 3.68 & 13.97 \\
\hline Swati et al, ${ }^{25}$ & 80.83 & 1.2 & 17.6 \\
\hline Present study & 74.4 & 3.4 & 22.2 \\
\hline
\end{tabular}

On the basis of cell of origin, frequency in the our present study was found to be $64 \%$ of Epithelial tumours, $29 \%$ of Germ Cell tumours, $1.16 \%$ of Sex Cord Stromal Tumours and $4.65 \%$ of Metastatic Tumours , so the results were closer to Couta $\mathrm{F}$ et al, with $68.81 \%$ of Epithelial tumours, $20.39 \%$ of GCT , $8.3 \%$ of SST, $1.46 \%$ of Metastatic Tumors and Swati et al, with $69.17 \%$ of ET , $25.83 \%$ of GCT , $4.17 \%$ of SST and 0.83 $\%$ of Metastatic Tumours (Table 7). ${ }^{22,25}$
Whereas Badge $\mathrm{S}$ et al, showed $77 \%$ of Epithelial tumours, $16 \%$ of GCT, $6 \%$ of SST, and $1 \%$ of Metastatic tumours and a study done by Jha R and Karki. S showed $52.2 \%$ of Epithelial Tumours, $42.2 \%$ of GCT, $3.1 \%$ of SST and $2.4 \%$ of Metastatic Tumours (Table 7). ${ }^{17,24}$ In the present study, majority of the tumours were benign $(74.4 \%)$ followed by malignant tumours $(22.2 \%)$ and rest was borderline $(3.4 \%)$. Findings of the present study correlated well with the studies of various authors as 
shown in table 8 . However, in this study the frequency of malignant tumours $(22.2 \%)$ was little less than the study of Gupta Et al, (40\%). ${ }^{16}$ This is probably because the study was undertaken in an institutional hospital and malignant tumours when diagnosed before surgery get referred to speciality oncology centres (Table 8).

\section{CONCLUSION}

It is concluded from this study that the tumors originating from surface epithelium are the commonest variant. Due to vague symptoms, patients present late and hence prognosis becomes poor by the time ovarian malignancy is diagnosed.

Majority of them were benign. The ovarian tumors manifest a wide range of clinical, morphological and histological features. Benign ovarian tumors form a very important clinical entity for a gynaecologist. Differentiation between a benign and malignant tumor is many a times difficult and Histopathological study remains the gold standard for the proper classification and management of ovarian neoplasm and there is a vast scope for reaching specific and reliable diagnosis of difficult dilemmatic cases of ovarian tumours, by which the therapeutic and prognostic implications could be modified.

\section{ACKNOWLEDGMENTS}

Authors would like to thank the patient and her attendants for their consent to publish the case.

\section{Funding: No funding sources}

Conflict of interest: None declared

Ethical approval: The study was approved by the Institutional Ethics Committee

\section{REFERENCES}

1. Day NE, Krishnan E. Epidemiology of gynaecological cancers. In: Shaw RW. Textbook of gynecology. $\quad 2^{\text {nd }}$ Ed. Edinburgh: Churchill Livingstone; 1997: 477-487.

2. Lora HE, Edyta CP, Husain AN. The Female genital tract. In: Kumar V, Abbas AK, Fausto N, Aster JC (Eds.) Robbins and Cotran's Pathologic Basis of Disease, $8^{\text {th }}$ edition. Philadelphia, Saunders-Elsevier; 2010:1039-1052.

3. Swamy GG, Satyanarayana N. Clinicopathological analysis of ovarian tumours- a study on five years samples. Nepal Med Coll J. 2010;12(4):221-3.

4. Rashid S, Sarwas G, Ali A. A Clinicopathological study of ovarian cancer. Mother Child. 1998;36:17-25.

5. Tortolero L, Mitchell FM, Rhodes HE. Epidemiology and screening of ovarian cancer. Obstet Gynecol Clin North Am. 1994;21(1):63-75.

6. Yasmin S, Yasmin A, Asif M. Clinicohistological pattern of ovarian tumours in Peshawar region. J Ayub Med Coll Abbottabad. 2008;20(4):11-3.

7. Juan R. Rosai and Ackerman's surgical pathology: ovary. 9th edn. Vol 2. New Delhi: Elsevier. 2004.
8. Murad A. Ovulation induction and ovarian tumours: the debate continues. J Pak Med Assoc. 1998;48(11):353-6.

9. Piver MS. Prophylactic oophorectomy: reducing the U.S. death rate from epithelial ovarian cancer: a continuing debate. Oncologist .1996;1(5):326-30.

10. Kumar V, Abbas AK, Asler JC. Robbins and Cotran Pathologic Basis of Disease, $9^{\text {th }}$ Ed. Elsevier Saunders, Philadelphia;2015:1023.

11. Fathalla MF. Incessant ovulation: a factor in ovarian neoplasia?. Lancet. 1971;2(7716):163-5.

12. Forae GD, Aligbe JU. A histopathological overview of ovarian lesions in Benin City, Nigeria: How common is the functional cyst? Int $\mathbf{J}$ Med Pub Health. 2014;4(3):265-8.

13. Bhattarcharya MM, Shinde SD, Purandare VN. A clinicopathological analysis of 270 ovarian tumors. J Postgrad Med. 1980;26(2):103-7.

14. Pachori G, Meena US, Sunaria RK, Pachori P, Jethani N, Bayla T. Histopathological study of ovarian tumors in Ajmer region. Int J Med Sci Pub Health. 2016;5(7):1400-3.

15. Mondal SK, Banyopadhyay R, Nag DR, Roychowdhury S, Mondal PK, Sinha SK. Histologic pattern, bilaterality and clinical evaluation of 957 ovarian neoplasms: A 10- year study in a tertiary hospital of eastern India. $\mathbf{J}$ Can Res Ther. 2011;7(4):433-7.

16. Gupta SC, Singh PA, Mehrotra TN, Agarwal R. A clinic pathological study of ovarian tumours. Indian J Pathol Microbiol. 1986;29(4):354-62.

17. Badge SA, Gosavi AV, Sulhyan KR. Histopathological study of ovarian tumors. Indian Med Gazette. 2013;345-51.

18. Sharma I, Sarma U, Dutta UC. Pathology of ovarian tumours: a hospital based study. Int J Med Sci Clin Invention. 2014;1(6):284-6.

19. Mankar DV, Jain GH. Histopathological Profile of Ovarian tumours: A twelve year institutional experience. Muller J Med Sci Res. 2015;6(2):107-11.

20. Prabhakar BR, Kalyani M. Ovarian tumorsprevalence in Punjab. Indian $\mathbf{J}$ Pathol Mirobiol. 1989;32(4):276-81.

21. Misra RK, Sharma SP, Gupta U, Gaur R, Misra SD. Pattern of ovarian neoplasms in eastern UP. J Obstet Gynecol. 1990;41(2):242-6.

22. Couto F, Nadkarni NS, Rebello MJ. Ovarian tumours in Goa: a clinic pathological study of ovarian tumours. J Obstet Gynaecol India. 1993;43(3):408-12.

23. Kar T, Kar A, Mohapatra PC. Intra-operative cytology of ovarian tumors. J Obstet Gynecol India. 2005;55(4):345-9.

24. Jha R, Karki S. Histological pattern of ovarian tumors and their age distribution. Nepal Med Coll J. 2008;10(2):81.

25. Singh S, Saxena V, Khatri SL, Gupta S, Garewal J, Dubey K, et al. Histopathological evaluation of ovarian tumors. Imp J Interdisciplinary Res. 2016;2(4):435-9. 
26. Kuladeepa AVK, Muddegowda PH, Lingegowda JB, Doddikoppad MM, Basavaraja PK, Hiremath SS, et al. Histomorphological study of 134 primary ovarian tumors. Adv Lab Med Int. 2011;1(4):69-82.
Cite this article as: Chandra K, Arora N.

Clinicopathological analysis of ovarian tumors: a two-year retrospective study. Int J Reprod Contracept Obstet Gynecol 2019;8:3015-20. 